\title{
Exploring change in small firms' HRM practices
}

\author{
Wapshott, R., Mallett, O., \& Spicer, D.
}

The academic literature widely acknowledges changes and variation in the practices of small firms but only a small amount of empirical work has explored the processes through which HRM practices undergo change. Research has tended, instead, to examine the presence and effectiveness of HRM in small firms and often viewed this in terms of a deficit model relating such practices to an understanding of HRM derived from larger firms. This chapter focuses on the recruitment and selection and staff payment practices in use in three small services firms to explore the everyday, ongoing detail of their HRM processes and practices. Identifying the different processes through which recruitment and selection and staff payment practices changed in the participant firms provides a base for discussing persistent forms of informality and the lack of stability that reflects the everyday realities of the firms, not only in contrast to their formalized policies but in engagement with them. This chapter advances understanding of selected HRM practices in small services firms after periods of formalisation and adoption of HRM policies and practices. The chapter also discusses how developing knowledge of small firms' HRM practices in this way has implications for researchers and practitioners.

Keywords: recruitment, pay, small firms, HRM, informality, services 


\section{Introduction}

Small firms are frequently more informal and ad hoc than their larger counterparts, subject to turbulent internal and external environments in which they encounter complex, interacting forces influencing their operation such as employees, clients and markets (Gill 1985; Wilkinson 1999; Ram et al. 2001). As small firms grow it has been argued that they introduce greater degrees of formality, for example in terms of more sophisticated Human Resource Management (HRM) policies and practices (Kotey and Sheridan 2004).

However, there are relatively few detailed studies considering the processes of how this HRM is adopted and may itself be subject to change as firms respond to turbulent operating contexts. This represents an important gap in research concerning the nature of HRM activities in small firms because static snapshots of these policies and practices may misrepresent, for example, the degree of ongoing change and lack of stability in their adoption, implementation and maintenance. Drawing on an 18 month case study of three small firms this chapter focuses on the firms' recruitment and selection and staff payment practices to explore these issues in detail. In doing so, we seek to develop understanding of small firm HRM practices and offer a broad characterization of changes in these practices in relation to persistent forms of informality relating to environmental turbulence, employment relationships and owner manager prerogative.

\section{Literature Review}

\subsection{HRM in SMEs}

One of the central themes of research into small firms' people management activities is acknowledging the heterogeneity of this group of organisations. The diversity of firms that may be gathered under the 'SME' banner underpins frequently identified definitional difficulties (Perren and Dannreuther 2013) but also raises problems when seeking to compare firms' practices. A medium sized firm of 
240 people is likely to differ significantly from a small firm with 24 employees. The influence of owner managers, business objectives, stage of organisational development and the nature of work undertaken in organisations have all been discussed as ways in which organisations may differ in how they approach HRM. In particular, the often related considerations of owner manager influence and organisational objectives demonstrate how simple assumptions around management control and profit maximization may not apply to all, or even a majority, of small firms. When discussing SMEs or, as in our focus, small firms with fewer than 50 employees, it might not be possible to identify every way in which firms differ but it remains important to understand which differences may be more or less important and therefore whether certain firms may in fact be comparable.

Furthermore, there is a risk in discussing 'HRM' in the broad SME literature that it is considered from a deficit position; it identifies what small firms are not doing or have not got in place when compared against a formal set of 'HRM' practices and policies. This is at odds with more general conceptualizations of small firms which recognize that comparisons between small firms and their larger counterparts do not represent the best way to understand these firms (Welsh and White 1981; Taylor 2005). Adapting conceptualizations of HRM processes from the large firm literature is an implicit way of holding the same comparison. Where existing studies often focus on debating the presence of HRM in smaller firms (for example, Taylor 2005), we suggest that the debate should be less about whether or not some form of HRM exists in small firms but more about what functions it performs and how or when it is utilized. For example, such studies of HRM practices could focus on why they are there, how they work, how they reflect or protect particular interests and at what cost or benefits.

In attempting to understand the dynamics of HRM practices it is important to acknowledge that small firms may not only differ from one another but also differ from larger firms in several important ways (Torrès and Julien 2005; Curran 2006) that may significantly alter how such practices are adopted and put into use over time. For 
example, the development, or emergence, of HRM practices and routines is subject to varying degrees of influence from external environmental factors. Rainnie's (1989) typology of relationships between small firms and their larger counterparts emphasizes the vulnerability of some small firms and the implications this could have for their employment practices. The potential vulnerability of small firms to competitors and in particular to their clients' demands might be explained, in some instances, by their relative 'resource poverty' (Welsh and White 1981; Cassell et al. 2002) which leaves them unable to absorb shocks from the market. However the nature of client influence in any given instance is known to vary (Beaumont et al. 1996; Kinnie et al. 1999; Kinnie et al. 2005). So, while clients are acknowledged as playing a potentially important role in shaping small firms' HRM practices, the varying nature and extent of any influence makes their impact hard to generalize.

Small firms, further, are potentially less likely to have collective bargaining or trade unions (Dundon et al. 1999), they lack internal labor markets (Westhead and Storey 1996) and tend to have more centralized decision making (Rodwell and Shadur 1997). Management practices in small firms are acknowledged to be less formal and less strategic than those found in larger businesses (Beaver and Prince 2004). Their cultures are shaped, at least initially, by owners whose goals and desires are communicated directly to employees in a context of close spatial and social proximity (Marlow and Patton 1993; Jennings and Beaver 1997), which also fosters informal relationships and working practices that are generally flexible and quick to change and adapt (Gilman and Edwards 2008; Mallett and Wapshott 2014).

The owner managers of small firms are traditionally acknowledged to exert influence over the practices in use (Jennings and Beaver 1997; Matlay 1997). However such influence can be tempered by the assertion of employee interests; employees are not passive recipients of owner manager control. The presence of family or social ties in a workplace (Ram 1994) and the relative importance of an employee's role to the business operation (Moule 1998) can shape the employment relationship. As a result, HRM within small 
firms can become a product of informal negotiations and mutual adjustment between owners and workers (Ram 1999a; Wapshott and Mallett 2013), creating more complex and subtle relationships than are commonly recognized in assumptions of owner manager dominance (Ram and Holliday 1993; Jones 2003).

Whilst such differences are a matter of degree and not kind (Ram and Edwards 2010: 238), this relative informality (Ram et al. 2001; Watson 1995) can be clearly seen in respect of HRM activities (Beaver and Prince, 2004; Kok and Uhlaner 2001; Matlay 2002), for example relying on an owner manager's personal networks for staff recruitment, informal evaluation of training needs and pay setting processes (Matlay 1999). Verreynne et al. (2013: 406) argue that the "scarcity of resources drives diversified and divergent employment systems" in small firms, especially in their early stages of development. Within such a context, HRM practices are considered to evolve such that ad hoc practices become informal routines for addressing various organisational challenges (Scott et al. 1989) and there is a general expectation that formality in HRM practices will increase as businesses grow (Kok and Uhlaner 2001; Kotey and Slade 2005), enhancing their competitive advantage (Sheehan 2013). Such formalisation has been widely related to business growth and a sense of maturation (Phelps et al. 2007).

HRM practices in small firms can be seen as products of not just single, isolated factors but also interactions between multiple influences. There is a need to understand HRM practices in small firms as they develop over time, understanding these everyday, ongoing processes in their own right rather than how they are deficient in relation to larger firms. The impact of these interactions and ongoing processes can be explored in relation to two aspects of HRM practice that are necessary to any commercial firm: recruitment and selection and staff payment.

\subsection{Recruitment \& Selection and Staff Payment}

Recruitment and selection is an area identified as problematic for many small firms because, while an owner manager may reserve the 
right to select who they wish, they might not be able to attract the very best workers in a given field (Scholarios and Lockyer 1999) or find sufficient employees with the requisite level of skills (Carroll et al. 1999; Harris 2002). The reasons for such problems vary but may include the levels of pay on offer (Ram 1994), the state of the labor market and the lower levels of perceived legitimacy for smaller firms as employers (Williamson 2000).

In response to such difficulties small firms may reject such formal 'sophistication' (Jameson 2000; see Taylor 2005) and focus on tried and tested methods to maximize information on applicants before making a selection decision (Marlow and Patton 1993; Cassell et al. 2002). Techniques include taking advantage of competitors or other firms making redundancies (Holliday 1995; Marchington et al. 2003), exploiting networks (Leung et al. 2006), staff recommendations (Carroll et al. 1999), employment agencies (Carroll et al. 1999; Holliday 1995), advertising (Heneman and Berkely 1999) and word of mouth (Cassell et al. 2002). The nature of recruitment and selection practices might therefore be described as often informal and reflecting the wishes of an owner manager but moderated by the position occupied by some smaller firms within the wider labor market. Whilst there is an assumption in the literature that such practices become more formal as firms grow (Phelps et al. 2007), not enough is known about the ways in which such formalized practices change in response to other pressures or during shorter time frames.

Pay arrangements in small firms may also be characterised by their informality and the degree of discretion accorded to the employer within the context of external influences (Gilman et al. 2002; Arrowsmith et al. 2003). Within this employer dominated context there may be scope for employee consultation but it is not always apparent how far these employee views influence salary levels (Curran et al. 1993; Forth et al. 2006; Wapshott and Mallett 2013). The primary importance of owner managers in setting basic pay levels is also apparent in relation to contingent rewards, where bonus payments represent another area of management discretion (Gilman et al. 2002). More generally, however, contingent forms of employee 
reward are relatively uncommon in smaller firms (Bacon et al. 1996; Jack et al. 2006) not least because of difficulties associated with their adoption (Cassell et al. 2002). The degree of owner manager discretion associated with pay practices in small firms suggests that they can be changed if the owner wishes.

Both recruitment and selection and staff payment can be seen as potentially subject to change, albeit driven by different blends of influences in the firms' environments. The relative informality of practices in use and complex interactions of influences shaping HRM practices in small firms can result in an appearance of adhocracy (see Wapshott and Mallett 2013) regarding employment matters, although the ad hoc nature of these practices may reduce through routinisation (Scott et al. 1989) or through formalisation as firms grow (Kotey and Slade 2005; Phelps et al. 2007). What the existing literature does not currently explore to any great extent are the processes of how changes in formalised HRM practices occur. In other words, existing knowledge highlights that change occurs and indicates the factors that may serve to bring this about (Jack et al. 2006; Rutherford et al. 2003) but there is little insight on how these changes operate, how the practices in small firms are formed and reformed over time (Arrowsmith et al. 2003). This chapter presents and discusses findings on the processes and experiences of changes in recruitment and selection and staff payment practices at three relatively formal small firms.

\subsection{Small professional service firms}

Service organisations are interesting for HRM research because highly skilled, specialist employees are integral to service transactions (Redman and Matthews 1998) and part of the interface with clients (Mills et al. 1983). They are therefore relied upon to generate income (Doorewaard and Meizhuizen 2000) by creating bespoke, intangible solutions to complex client problems (Morris and Empson 1998: 610). How such relatively autonomous employees (Goffee and Scase 1995) are managed therefore impacts greatly upon business outcomes (Boxall 2003). 
Unlike their counterparts in less skilled small firms, specialist workers in small professional service firms are likely to have a potentially stronger bargaining position in shaping their employment relationships (Behrends 2007). Their employers may therefore be required to manage these valuable resources in different ways from lower skilled and more abundant workers (Scase 1995, 2005; Ram and Edwards 2003). HRM practices can be used to moderate the relationship between these organisations and their workforces (Boxall and Steeneveld 1999; Tam et al. 2002) and more formal practices have been identified in specialist small firms than the somewhat informal and 'unsophisticated' picture presented elsewhere (Swart and Kinnie 2003; Jameson 2000).

They therefore represent a useful type of small organisation to explore the enactment and utilisation of formal HRM practices over time. Research exploring the relative informality of smaller firms, together with the particular type of influence held by specialist workers, has the potential to produce different insights into the adoption and development of HRM in practice. However, the development of working practices and HRM in small professional service firms and other small, knowledge intensive organisations remains relatively under researched, despite their importance for many economies (Ram and Edwards 2010).

\section{Method}

This research set out to explore in detail the employment relationships and HRM activities of three small professional service firms. We adopted a multiple case study strategy (Yin 2003) with the data collection concentrated into two main phases, approximately 18 months apart and covering up to three weeks at each organisation. Contact was maintained with the firms between the main data collection phases. In addition to meetings with management, email and telephone interactions with employees helped to maintain relationships and deepen knowledge of practices and general workings of the companies. Incorporating a longitudinal component (Gilman et al. 2002; Jack et al. 2006) into the research design was important to identifying any changes in practice occurring. 


\subsection{The Firms}

For this study businesses were selected with fewer than 49 employees and falling within Morris and Empson's (1998: 610) broad definition of a professional service firm as one "that trades mainly on the knowledge of its human capital, that is its employees and the producer-owners, to develop and deliver intangible solutions to client problems...the products of the PSFs are generally more complex [in comparison with other service companies] and, crucially, can be bundled in a variety of ways to customize solutions to the client's specific circumstances." Two of the participating businesses were specialist recruitment companies and the third was a design and communications company in which one of the founding directors was Chartered Institute of Personnel and Development (the UK's professional body for HR practitioners) trained and qualified giving these firms greater formal HRM knowledge than is often associated with small firms (Marlow 2005).

The firms were accessed through personal networking among business contacts (Ram and Holliday 1993; Moule 1998) and targeted mailings. These approaches proved effective in overcoming the problems often associated with accessing small firms for research purposes (Blackburn 2005; Matlay 2002). These three firms were identified as having relatively formal HRM policies and practices, from some perspectives to have 'formalised' (Kotey and Sheridan 2004). Initially the recruitment businesses (FinRec and SciRec), which might be viewed as having business processes amenable to standardization, were complemented by two design and communications businesses, which might be anticipated to be more focused on innovation and non-standardized approaches to their work. However during the research period one of the design and communications firms out grew the business selection criteria and so is not presented here.

The businesses are identified by the pseudonyms FinRec, SciRec and ComCo and can be described as follows. 


\section{FinRec}

FinRec Limited specializes in the recruitment of permanent staff to leading players in the financial services and consumer credit industries. The precise nature of the service provided by FinRec depends on client requirements but can involve recruitment of individuals for replacement purposes or managing a project to recruit an entire team. When this research commenced, the business had been established for around 10 years. It was founded by the managing director, Graham, who had worked in retail finance prior to establishing FinRec.

During the research period the business employed between 12 and 16 staff, the majority of whom were consultants providing recruitment services to clients. Other staff roles included Sally, the operations manager, and some administrative support. Employees came from a variety of backgrounds including a former HR manager and university graduates as well as people with relevant work experience but without higher education qualifications.

\section{SciRec}

SciRec Limited is a contracted supplier of specialist recruitment services to scientific businesses. Additional, related services are offered such as psychometric testing and interview training. Tim, the owner manager, had spent his career working in the pharmaceutical industry fulfilling a similar role to that served by SciRec. The business had been operating for four years when this study started.

At the time of the initial fieldwork SciRec employed an operations manager, two recruitment consultants focusing on technical (Karen) and non-technical roles respectively, and two administrators. One of the administrators was on a fixed term contract and was the only member of staff without some recruiting responsibilities. During the second fieldwork phase five people were working for the company, however these were different from those employed in phase one. There was a recruitment manager (Chris) who fulfilled a very similar role to the one previously performed by 
the operations manager, a generalist recruiter who covered all nonscientific vacancies (Carly) and two scientific recruiters. One of these recruiters had a specific business development remit. One scientific consultant (Bethan) and the business development consultant were on initial fixed term contracts so that their abilities could be assessed before permanent appointments were made. The organisation also employed an administrator. Consultants and management staff were mostly graduates.

\section{ComCo}

Finally, ComCo is a design and communications consultancy offering public relations, strategic marketing, design and internal communications services. ComCo was in its third year of trading full time when the research started, although the company had been established for five years as the directors prepared to leave their respective employers. Three founding directors each owned shares in the business with two of them, Fred and John, each holding 35\% of the business. The remaining 30\% stake was evenly divided between the third founder and a longtime associate (Alan) who joined ComCo as a director.

Although originally serving local authorities and small businesses, ComCo focused increasingly on multinational companies with some success. The changing nature of its business had implications for ComCo's structure and there was some staff turnover including John who left following disputes over the business' direction. Along with some staff turnover, headcount at ComCo increased from 14 to 20 during the study divided across the core of PR / communications team and smaller teams for marketing and graphic design. The growth in staff numbers was accounted for by growth in the marketing and design functions.

\subsubsection{Data Collection}

Data gathering in the three companies included direct observations (348 hours), semi structured interviews (35) and reviewing company documentation (600 pages). The observations 
were used to gather data around employment relationships and the practices of managing employment relationships in each firm, beyond the formal and partial picture presented in written company HRM policies (Bacon et al. 1996). Drawing on such observations not only facilitated understanding of the research environment but also stimulated further questions and provided common ground to refer to in the semi structured research interviews with staff. One example of this was using observations on an incentive game at FinRec as a way into discussing performance management and targets with company employees. Additionally, this approach gave some scope to explore the potential for policy/practice tensions and contradictions that can be overlooked, for example in survey research.

Semi structured interviews were used to balance consistency across interviews while allowing some scope for discovering any informal or idiosyncratic approaches to HRM issues. The interviews, typically lasting 60 minutes, covered topics including how staff were hired and payment practices in the firm with a view to understanding the employment practices in each company. Care was taken to interview people who might be able to provide insight on specific topics, for example speaking to new starters who could talk about their experiences of recruitment and selection and staff induction.

Interviews were recorded with the permission of the interviewee and transcribed for analysis. Originally it was intended that interviewees from phase one would be re interviewed in phase two of the data collection however staff turnover, absences and the available research access limited the possibilities for such follow up interviews. Nevertheless, there were still sufficient opportunities to discover which practices were in use at different times of the study. Further, the high degree of change within the firms became a core area of focus within the study.

Informal discussions provided another means of data collection and were particularly important in FinRec during phase two because the owner manager was unwilling to release staff for further formal interviews. In addition to the single semi structured interview that 
was possible, staff were happy to discuss the company and their roles over lunch breaks and during quiet periods of work time. Notes from such interactions were written up immediately after the conversations to capture the details and then incorporated into the dataset for each business.

The observations and interviews were further bolstered by company documents. Initial discussions with the case study firms confirmed that, consistent with other SME research (for example Ram 1999b; Dundon et al. 1999; Grugulis et al. 2000) and the training of those within the companies, each had some formal people management policies so documents including HRM policies, internal memos and business plans were gathered where available.

\subsubsection{Data Analysis}

Data analysis was guided by Miles and Huberman's (1984, 1994) procedures for qualitative data analysis because these sourcebooks set out approaches to enable thorough and systematic analysis of qualitative data. Throughout the data collection phases the observation, interview and documentary data gathered were read and considered against existing data from this study and extant literature to stimulate thought and highlight shortfalls in the data collected up to that point (Miles and Huberman 1994). Further analysis was conducted at the end of the data collection phase via systematically applying pre-defined codes to interview transcripts, observation records and company documents to identify HRM practices in use.

Developing pre-defined codes, informed by the fieldwork, was driven by a need to order the data. The codes were designed to identify HRM practices around recruitment and selection, training and development, performance management, salary / pay, appraisal and staff exit, broadly following descriptions of HRM found in the work of Galbraith and Nathanson (1978) and Devanna et al. (1984) among others. Practices conforming to rigid definitions of HRM practices may not be found in smaller firms (Taylor 2005) so in this study the codes were interpreted broadly but consistently to permit comparison of practices in use. Coding was conducted by this 
chapter's first author while the codes and coding were checked independently for meaning and consistency by the chapter's coauthors.

\subsection{Findings}

While the literature suggests that some small firms' turbulent environments and informal practices will give rise to changes, it is the processes of how changes occurred that are of specific interest to this chapter. While our research explored a broad spectrum of HRM practices and areas of the employment relationship in the firms, two areas of HRM activity (recruitment and selection and staff payment) have been selected to provide sufficient scope for exploring the practices in use, rather than cover a wider range of practices in less depth. These findings therefore present examples of the ongoing, everyday changes within the formal HRM practices in the three firms.

One of the first things noticeable about the HRM practices found within these firms is that they are relatively sophisticated compared to what might be anticipated from many small firms (Cassell et al. 2002; Marchington et al. 2003; Forth et al. 2006). For instance in recruitment and selection, SciRec and FinRec report the use of some psychometric testing for staff selection or multiple stages of selection. While ComCo also adopted systematic and structured approaches to staff recruitment and selection and utilized head hunters to target suitable talent for the business. The firms, as providing professional services, might perceive a need to deploy relatively sophisticated HRM practices given the importance of staff to their businesses' success (Behrends 2007). Clearly, the complexity of recruitment and selection practices in the companies can be understood in terms of their business specialism (FinRec and SciRec) or training of an owner (John at ComCo). The owner managers' backgrounds, coming from large organisations with management practices that they imported into their own businesses, might also explain something of the apparent sophistication of practices in the firms. It might also lend weight to our impression that the formal policies were implemented sincerely to shape business practice 
rather than simply as 'window dressing' for clients' benefit (see Ram 2000). Another area of similarity between the firms, but one in which they were also more typical of small firms generally, was in the changing nature of their practices.

Where staff payment practices were concerned, in all three firms pay rates were determined to varying degrees at the discretion of the owner manager or management team, consistent with what might be anticipated from extant literature. Nevertheless, FinRec and SciRec offer evidence of performance related pay schemes, which may be considered unusual in the context of small firms (Cassell et al. 2002; Gilman et al. 2002). The approach of ComCo to staff payment was interesting in its own way so far as it appeared closely tied to the company's development towards working with blue chip clients.

During the 18 months covered by this study, each of the firms displayed changes in their formal recruitment and selection and staff payment practices. We present and discuss these findings in terms of the three key themes that emerged in our analysis of the change processes relating to HRM practices: enduring, adaptive change in response to external operating environments, fluctuating, continuous change and short term periods of trial and error. In presenting these three themes our aim is not to categories types of change in small firms' HRM practices but to seek to characterize the different processes through which such changes come about.

\subsubsection{Enduring adaptation}

Enduring changes, in so far as can be identified from this study, emerged in ComCo's recruitment and selection and payment practices through adaptive responses to external pressures and became established features of its approach to HRM. These changes were initiated during the first phase of onsite research which founding owner manager John described with an emphasis on cost control regarding staff salaries:

In taking people on it's always about, you know, the balance of risk and reward. You know, you're committed to 
pay them a certain amount of money which puts pressure on the business to earn more money.

Such concerns over employment costs were balanced by a need for salary levels to retain good staff in a competitive client and labor market:

When we get them, people, to the level we'd like, we are paying them above [the average]. This is a business [industry sector] where people move around a lot. We want to keep people because they, because it's such a relationship based business, if you were to lose them you are in danger of losing the client because the client likes to see that person. (John)

However 18 months later the business had undergone significant changes, reflected in ComCo's approach to staff payment. Tensions arising in the business had reached a breaking point. John had left the business in a disagreement over the direction it was taking and the demands this placed on his work life balance, and his original business partner Fred had become the managing director. Although company director Alan coyly described this process as being "as amicable as it could be", others, including Fred himself, acknowledged that John's exit had been a strained process. Following John's departure the original caution regarding wage costs had disappeared in the moves to employ staff with greater experience who were better able to meet the needs of ComCo's new clients and who could work independently of the management team. Fred explained that the change in focus had increased the wage bill by around $25 \%$ but he asserted that the relatively high fees earned from large clients justified the increased costs. Thus, the approach to pay was largely dictated by the bargaining power of employees trusted by external clients who were in turn supported by what were perceived by Fred as the pressures of the external labor market.

At FinRec, consultant grade staff received a basic salary plus commission on revenue earned above an accepted threshold. The threshold varied with staff grade so senior employees with higher basic salaries had to generate more money than junior staff before 
they started to earn commission. FinRec operations were designed to deliver certain levels of financial returns to managing director Graham and, in addition to influencing recruitment and selection activities, this also shaped contingent pay arrangements. During one of several conversations with the researchers between the main onsite research phases, Graham and Operations Manager Sally explained how two of FinRec's major clients froze their recruitment budgets when experiencing a downturn in trade. In response, FinRec rapidly made three redundancies and raised the commission threshold to keep the business on track for Graham's financial targets. For the majority of consultants this meant having to earn the business an additional $12 \%$ of revenue before they received any commission.

Although this change in pay arrangements appeared significant, staff were already accustomed to their targets being raised. In relation to a further target change, the staff seemed resigned to accept Graham's authority to alter commission without consultation: "at the end of the day, he's the boss that means what he says goes." (Mary, Consultant) and "You had your moan and that was it. Well, it's gotta be done so, I think everybody had their [grumbles] but there's nothing we could do about it" (Lorraine, Consultant). Even as the clients started spending again, however, the changes remained in place. For the staff at FinRec, the changes in pay arrangements were seen as part of normal business and Graham's prerogative.

In some respects adaptations such as these might be viewed as the successful (if somewhat opportunistic) improvisations or trials, those sustainable responses to shifts in firms' operating environments. Certainly both organisations changed in response to client related issues but the changes can also be seen as consistent with the respective organisational strategies and power within each business consolidated in the owner manager's prerogative. ComCo wanted to attract and employ staff able to serve the new client base it was winning, and FinRec needed to keep delivering returns for Graham. The changes and, importantly, maintaining them can be seen as high priorities of those running the firms. Moreover, perhaps reflecting this priority status, there was management resolve to see these 
changes succeed. These appear close to a fairly strategic approach to HRM activities but were not representative of all practices in these firms.

\subsubsection{Fluctuating practices}

Evidence from SciRec suggested that, despite possessing sophisticated procedures for recruitment and selection and using them at various times, practice in this area shifted without discernible rationale. Although owner manager Tim explained the almost continual change as resulting from business pressures, staff hired at different times when such pressures were absent still reported various approaches to their recruitment and selection experiences.

Despite possessing the most seemingly sophisticated selection tools of all the companies studied, Tim described how formal employee selection processes had been relaxed during a period of high client demand. One specific consequence, attributed by Tim to this relaxation, was a consultant being appointed who was unsuitable for the firm and, as a result, Tim resolved to use the battery of tests and techniques available:

So after that we said "OK, we're going to put them through a process" so we now put everyone through at least [psychometric test] plus at least two interviews, possibly a presentation, they get to talk with the team, you know to have a 10,15 minute chat with each of the team, to try and make sure we get the right people 'cause we're saying to our clients "You need to put people through a more robust process" and we weren't, so we need to sort of practice what we preach

However employee accounts gathered in phase two revealed that practices continued to alter, even outside busy periods cited by Tim as causing the earlier shifts in practice. The consultants described their different selection experiences. Carly described her experience: 
I came in and spoke to Chris [recruitment manager] for half an hour, then spoke to Tim for I suppose about half an hour. The feedback I got from that was that they weren't sure I was confident enough for the position...So I was invited in for a second interview [including presentation to the team] to see if I could prove them wrong and, I don't know, for lack of other candidates or whatever, I got the job!

Others explained how, in addition to interviews, they had been placed on a temporary contract by way of indefinite trial period. Bethan (consultant):

The first interview was really, Chris gave me an introduction about what SciRec does, and what they were looking for. He emphasized the recruitment side and also the sales side as well, erm, and then he was generally just sort of asked me questions with regards to my personality and I just sort of told him how brilliant I was! The second wasn't really an interview it was just sort of signing a contract, which actually turned out to be a temp contract, not a permanent contract...

The fluctuating practices detected at SciRec may indicate that Tim's sophisticated practices were unsuitable for such a small business (Heneman and Berkley 1999) and may indicate some of the problems associated with trying to balance informal and formal processes in a small firm (Gilman and Edwards 2008). With Tim managing the business on a daily basis it is understandable that he may lack the time to implement the formal processes that he used in support of his successful Investors in People accreditation and recommends to much larger client organisations. As a result, the informal, ad hoc approach associated with small firms before they formalize and adopt HRM policies and practices persisted in SciRec, despite the sophisticated tools at their disposal and adopted when circumstances allowed.

The pressure to 'practice what we preach' without the resources to do so may help explain Tim's dogged insistence on formal processes 
even if they are subject to persistent informality and continual change. Another example of informally driven continuing change was found where Tim revised the commission structure several times within the previous 12 months. Tim was attempting something many small firms struggle with, designing an effective performance related pay system (Cassell et al. 2002). A desire to establish a complex reward structure while seeming to lack the necessary knowhow may underlie the ongoing adjustments to consultants' commission arrangements. Tim's actions created an impression of ad hoc or almost improvised approaches to these areas of practice. Closer consideration identified a frustration at the disparity between his desire for consistent, sophisticated formal practices and his ability to realize them in everyday practice.

Such continual change, without apparent pattern, may be characterized as fluctuating and this form of change was often attributed to external pressures, demands or opportunities. For example, a firm may adopt a practice dictated by a large client which does not become an embedded practice but, rather, is soon discarded or ignored. Owner manager centrality in the firms was such that, despite high degrees of formality, informal, ad hoc decision making persisted in response to pressures, irrespective of written HRM policies. They also suggest that, with such continual changes, the prospects for gradual routinisation of practices are low.

\subsubsection{Short term trial and error}

At FinRec, despite some enduring, adaptive changes, influential forms of informality also persisted in altering the ongoing, everyday HRM practices. Staff requirements were driven by Managing Director Graham's budget for the year. Graham calculated the required headcount by dividing his financial target by his view of what revenue each consultant should generate, as operations manager Sally explained:

We've got at the end of the year, erm, a figure that Graham wants to achieve. To ensure that we get to that figure we need $\mathrm{X}$ amount of people within this business producing. So 
that's kind, that's the kind of goal as well. You've also got to see and plan for people who may leave. It's not a job whereby you start one week and the next week you're earning [revenue for the company]

FinRec staff were usually selected for employment at the end of a carefully organised process, features of which were copied from their clients' business practices. As explained by team leader Maggie, often the first contact made by FinRec with an applicant was by phone. A brief conversation assessed whether they might be suitable for interview, the principal selection tool. Two interviews were held, first with the two team managers and then a second round with either Sally (the operations manager) or Jenny (the managing director's wife and ad hoc employee).

The selection interviews normally took place on different days and included a "branch visit" when the applicant would shadow a consultant for a short period by way of job preview. Consultants described how some of them had sat selection tests, for example an in tray exercise or a job related personality test. The selection process did not end on appointment however, as staff unable to achieve their targets within the six month probationary period were usually dismissed.

However, employee selection at FinRec did not always occur in this way. Sally explained that when a number of consultants had left the business in quick succession FinRec had insufficient headcount to remain on target for revenue generation. Graham responded by exerting pressure on Sally to fill these positions rapidly, which had implications for the selection processes. Sally compressed both personal interviews and the branch visit into one day and lowered the standard of applicant appointed. Sally explained how she had acted in order to meet rapidly the headcount requirement: "Sometimes you do that, you go into panic mode."

Having overseen the under performance and dismissal of staff appointed hastily, Sally reflected that FinRec would have to return to a more controlled selection approach: 
I'm conscious now, we need another three people. I could quite easily have thought last week: "They're borderline these two, let's just get them in, let's get them in". But I'm not doing that this time. It might affect revenue but then I think: "Well what's the point of getting somebody in for a couple of months and then I have to get rid of them?" because it's not fair to them. It's not fair to us.

Changes brought about by informal pressure from Managing Director Graham to the recruitment and selection practices were introduced reflecting a degree of owner manager prerogative but then quickly reversed when the new system led to what were perceived as poor selection decisions. Departures from established practices or routines were short lived as undesired consequences caused a reversion to those established practices even though they were also recognized as having some associated costs. Such short lived changes, reverting to established practices, may be characterized in relation to persistent informality engaging over time with formalized, written polices and associated practices.

At SciRec, Tim's most recent changes to commission structures came after a previously unsuccessful attempt at revising them. On that occasion the consultants in post resisted his new approach for fear of losing money. During the first research phase there was an intricate combination of contingent pay arrangements in operation at SciRec. Tim described these schemes as a reward and an incentive for filling client vacancies, which earned revenue for the firm. However the consultants perceived inequity in the system because, under its complex rules, certain vacancies attracted commission while other, similar ones did not. Tim's initial attempt to impose changes to the performance related pay schemes was successfully opposed by the consultants who argued they would lose hundreds of pounds each month under the revised system. As a result, on this occasion, pay arrangements reverted to the previous formal system.

These practices at FinRec and SciRec may highlight the use of 'trial and error' in adjusting formal practices in small firms. In both 
instances changes were aborted once greater problems emerged than those they were seeking to overcome. Given the speed at which the consequences of an often informal, adhocratic decision to alter recruitment and selection or staff payment practices occurred, the nature of changes to practice represent a lack of stability and strategic direction even though a new system may eventually be arrived at. While such enduring changes may, eventually, result from a period of routinisation this process appears turbulent and responsive to informal influences and forms of negotiation and mutual adjustment (Ram 1994; Wapshott and Mallett 2013).

For FinRec and SciRec the owner managers often asserted that there was a clear understanding of what their businesses needed in order to succeed but that there were barriers to succeeding in the changes. Recruiting staff unable to meet Graham's financial goals for the business would represent a failure, as would a major revolt by consultants in Tim's business. In the latter instance the professional services nature of the companies in this study may heighten the extent to which expert employees can assert their wishes in respect of changes to HRM practices owing to their importance to the business (Tam et al. 2002; Swart and Kinnie 2003; Swart 2007). In both cases many decisions were arrived at informally, through owner manager prerogative or ad hoc negotiation with employees, not through the formalized systems and processes that the firms would present to external audiences.

\section{Conclusion}

In this chapter we have suggested that small firm HRM needs to be considered as distinct and researched on its own terms, attentive to ongoing, everyday practices. There is a risk with 'HRM' as discussed in the broad SME literature that it is from an inherently deficit position; it identifies what small firms are not doing or have not got in place (Taylor 2005). Adapting conceptualizations of HRM processes from the large firm literature is an implicit way of holding an unhelpfully direct comparison between these very different kinds of firms. Small firms are different and, as such, our research has demonstrated one way in which their approaches to HRM practices 
can be understood on their own terms. Where existing studies often focus on debating the presence of HRM in smaller firms, we suggest that the debate should be less about whether or not some form of HRM exists in small firms but more about what functions it performs and how or when it is utilized (see Taylor 2005).

While it is known from existing work that changes occur in small firms' HRM practices, our findings suggest something of how those changes come about. The changes in recruitment and selection and staff payment practices are consistent with notions of HRM in small firms being relatively ad hoc and informal and, importantly, our research demonstrates the ways in which such informality persists even when formal policies and practices are in place. The persistent informality of small firms influences how formality is practiced in the business and contributes to a diversity of experiences both between and within firms when it comes to changes in those practices.

The findings indicate retain a degree of discretion with regards to certain HRM activities in their firms, albeit within the constraints of their operating context (Ram 1994; Moule 1998; Arrowsmith et al. 2003). On this basis it may be possible to speculate that the particular balance of discretion and constraints in respect of practices come to shape the processes of how change occurs and HRM is enacted. For example, where an owner manager, or firm, possesses the discretion to implement changes and faces constraints in terms of resources, opposition or knowhow, short term changes to practices may occur. In contrast, where the discretion to alter practices is faced by no constraints, or constraints that can be readily overcome, enduring adaptation in HRM practices may be the result.

In the case of internal resistance and the constraints placed on owner managers by staff, this supports the notion of employees as not simply being passive recipients of owner manager control. Whilst employee influence is likely to be greater, more explicit and with more force behind it in professional service firms than lower skilled firms, different forms of negotiation and resistance may still limit the degree to which HRM practices can be adapted and 
embedded in the long term. It is also important to acknowledge the powerful forces exerting influence from outside many small firms, albeit forms of influence owner managers may accede to only superficially or in the short term. The forms such tensions and constraints take play important roles in the development and practice of HRM within small firms.

The potential for fluctuating, continuously changing formal practices or more short term trial and error approaches demonstrates limits on owner manager prerogative as well as something of the ways in which they seek to impose their desired forms of management over longer time frames as they seek to adapt HRM practices. These processes also suggest a risk of cross sectional studies of small firms that may miss these forms of change and the negotiations, constraints and tensions they reflect. Instead, such studies might inadvertently present relatively stable, strategic impressions of HRM practice and the ways in with processes change with firm size, formalisation and in response to particular, rationally understood demands or challenges. Importantly, this study suggests forms of persistent informality that continue to influence ongoing, everyday practices after firms appear to have formalized and introduced written HRM policies.

Building on work that identifies that change occurs and the factors involved in promoting changes to create a picture of ad hoc informality, our findings suggest something of how those changes come about. The processes of how changes in recruitment and selection and staff payment practices occurred highlight that, while small firms may be largely reactive to their environment and ad hoc and informal in their approaches to HRM, the processes underpinning the forming and reforming of practices in use can differ when understood over the longer term and on an everyday basis. Understanding more about when and why these differences occur can advance understanding of HRM in small firms.

It can be suggested that recognizing how small firms' HRM practices alter in different ways may cause practitioners to reflect on the chances of HRM practices being successfully implemented and 
developed. The predominantly informal and ad hoc ways of organizing employment relationships, and other aspects of small firms, while not always ideal may suit the degrees of flexibility required by a firm's environment. Opting for particularly formal approaches to employment relationships may reduce this flexibility in favor of standardized processes that exist in tension with how a business operates. Judging when is the optimal time to increase degrees of formality, however, remains a matter of judgment (Phelps et al. 2007) so practitioners should proceed with caution.

Researchers might consider further the differences in how changes to HRM practices in small firms occur and more generally question whether the practices they find currently in use are relatively stable, part of a broader process of trial and error or undergoing other processes of change. In this context, we suggest the importance of attending to persistent forms of informality for understanding even formalized firms with sophisticated HRM policies and practices. For both practitioners and researchers these initial findings suggest that there is value in deepening the characterization of small firms' HRM practices as ad hoc and informal. 


\section{References}

Arrowsmith, J., Gilman, M. W., Edwards, P. \& Ram, M. (2003). The impact of the National Minimum Wage in small firms. British Journal of Industrial Relations, 41(3), 435-456.

Bacon, N., Ackers, P., Storey, J. \& Coates, D. (1996). It's a small world: managing human resources in small businesses. International Journal of Human Resource Management, 7(1), 83-100.

Beaumont, P. B., Hunter, L. C. \& Sinclair, D. (1996). Customersupplier relations and the diffusion of employee relations changes. Employee Relations, 18(1), 9-19.

Beaver, G. \& Prince, C. (2004). Management, strategy and policy in the UK small business sector: a critical review. Journal of Small Business and Enterprise Development, 11(1), 34-49.

Behrends, T. (2007). Recruitment practices in small and medium size enterprises: an empirical study among knowledge-intensive professional service firms. Management Revue, 18(1), 55-74.

Blackburn, R. (2005). Researching the employment relationship in small firms. In S. Marlow, D. Patton, \& M. Ram, (Eds.), Managing labour in small firms (pp. 43-65). Abingdon: Routledge.

Boxall, P. (2003). HR strategy and competitive advantage in the service sector. Human Resource Management Journal, 13(3), 5-20.

Boxall, P. \& Steeneveld, M. (1999). Human resource strategy and competitive advantage: a longitudinal study of engineering consultancies. Journal of Management Studies, 36(4), 443-482.

Carroll, M., Marchington, M., Earnshaw, J., \& Taylor, S. (1999). Recruitment in small firms: processes, methods, and problems. Employee Relations, 21(3), 236-250.

Carroll, M., Smith, M., \& Oliver, G. (2008). Recruitment and retention in front-line services: the case of childcare. Human Resource Management Journal, 19(1), 59-74.

Cassell, C., Nadin, S., Gray, M., \& Clegg, C. (2002). Exploring human resource management practices in small and medium sized enterprises. Personnel Review, 31(6) 671-692.

Curran, J. (2006). 'Specificity' and 'denaturing' the small business. International Small Business Journal, 24(2): 205-210. 
Curran, J., Kitching, J., Abbott, B., \& Mills, V. (1993).

Employment and employment relations in the small service sector enterprise - a report. Kingston: Kingston University / Kingston Business School, ESRC Centre for Research on Small Service Sector Enterprises.

Dannreuther, C., \& Perren, L. (2013). Uncertain states: the political construction of the small firm, the individualisation of risk and the financial crisis. Capital \& Class, 37(1), 37-64.

de Kok, J. and Uhlaner, L. M. (2001), "Organization context and human resource management in the small firm", Small Business Economics, Vol. 17 No. 4, pp. 273-291.

Devanna, M. A., Fombrun, C. J., \& Tichy, N. M. (1984). A framework for strategic human resource management. In C. J. Fombrun, N. M. Tichy, \& M. A. Devanna, (Eds.), Strategic human resource management (pp. 33-51). New York: John Wiley \& Sons.

Doorewaard, H., \& Meihuizen, H. E. (2000). Strategic performance options in professional service organisations. Human Resource Management Journal, 10(2), pp. 39-57.

Dundon, T., Grugulis, I., \& Wilkinson, A. (1999). 'Looking out of the black-hole': non-union relations in an SME. Employee Relations, 21(3), 251-266.

Forth, J., Bewley, H., \& Bryson, A. R. (2006). Small and medium sized enterprises: findings from the 2004 Workplace Employment Relations Survey. London: Department of Trade and Industry; Economic and Social Research Council; Advisory, Conciliation and Arbitration Service; Policy Studies Institute.

Galbraith, J. R., \& Nathanson, D. A. (1978). Strategy

implementation: the role of structure and process. St Paul: West Publishing Company.

Gill, J. (1985). Factors affecting the survival and growth of the smaller company. Aldershot: Gower Publishing Company Limited.

Gilman, M. W., \& Edwards, P. K. (2008). Testing a framework of the organization of small firms: fast-growth, high-tech SMEs.

International Small Business Journal, 26(5), 531-558.

Gilman, M., Edwards, P., Ram, M., \& Arrowsmith, J. (2002). Pay determination in small firms in the UK: contours of constrained choice. Industrial Relations Journal, 33(1), 52-67. 
Goffee, R., \& Scase, R. (1995). Corporate realities: dynamics of large and small organisations. London: International Thomson Business Press.

Grugulis, I., Dundon, T., \& Wilkinson, A. (2000). Cultural control and the 'culture manager': employment practices in a consultancy. Work, Employment and Society, 14(1), 97-116.

Harris, L. (2002). Small firm responses to employment regulation. Journal of Small Business and Enterprise Development, 9(3), 296306.

Heneman (III), H. G., \& Berkley, R. A. (1999). Applicant attraction practices and outcomes among small businesses. Journal of Small Business Management, 37(1), 53-74.

Holliday, R. (1995). Investigating small firms: nice work?. London: Routledge.

Jack, S., Hyman, J., \& Osborne, F. (2006). Small entrepreneurial ventures culture, change and the impact on HRM: a critical review. Human Resource Management Review, 16(4), 456-466.

Jameson, S. M. (2000). Recruitment and training in small firms. Journal of European Industrial Training, 24(1), 43-49.

Jennings, P., \& Beaver, G. (1997). The performance and competitive advantage of small firms: a management perspective. International Small Business Journal, 15(2), 63-75.

Jones, O. (2003). The persistence of autocratic management in small firms: TCS and organisational change. International Journal of Entrepreneurial Behaviour \& Research, 9(6), 245-267.

Kinnie, N., Purcell, J., Hutchinson, S., Terry, M., Collinson, M., \& Scarbrough, H. (1999). Employment relations in SMEs: marketdriven or customer-shaped? Employee Relations, 21(3), 218-236.

Kinnie, N. J., Swart, J., \& Purcell, J. (2005). Influences on the choice of HR system: the network organization perspective.

International Journal of Human Resource Management, 16(6), 1004-1028.

Kotey, B., \& Sheridan, A. (2004). Changing HRM practices with firm growth. Journal of Small Business and Enterprise Development, 11(4), $474-485$.

Kotey, B., \& Slade, P. (2005). Formal human resource management practices in small growing firms. Journal of Small Business Management, 43(1), 16-40. 
Leung, A., Zhang, J., Wong, P. K., \& Foo, M. D. (2006). The use of networks in human resource acquisition for entrepreneurial firms: multiple 'fit' considerations. Journal of Business Venturing, 21(5), 664-686.

Mallett, O. \& Wapshott, R. (2014). Informality and employment relationships in small firms: humour, ambiguity and straight-talking. British Journal of Management, 25(1), 118-132.

Marchington, M., Carroll, M., \& Boxall, P. (2003). Labour scarcity and the survival of small firms: a resource-based view of the road haulage industry. Human Resource Management Journal, 13(4), 5-22.

Marlow, S. (2005). Introduction. In S. Marlow, D. Patton, \& R. Ram (Eds.), Managing labour in small firms (pp. 1-17). Abingdon: Routledge.

Marlow, S., \& Patton, D. (1993). Managing the employment relationship in the smaller firm: possibilities for human resource management. International Small Business Journal, 11(4), 57-64.

Matlay, H. (1997). The paradox of training in the small business sector of the British economy. Journal of Vocational Education and Training, 49(4), 573-589.

Matlay, H. (1999). Employee relations in small firms: a microbusiness perspective. Employee Relations, 21(3), 285-295.

Matlay, H. (2002). Industrial relations in the SME sector of the British economy: an empirical perspective. Journal of Small Business and Enterprise Development, 9(3), 307-318.

Miles, M. B., \& Huberman, A. M. (1984). Qualitative data analysis: a sourcebook of new methods. Beverley Hills / London: Sage.

Miles, M.B., \& Huberman, A.M. (1994). Qualitative data analysis: an expanded sourcebook. Thousand Oaks: Sage Publications Inc.

Mills, P. K., Chase, R. B., \& Margulies, N. (1983). Motivating the client/employee system as a service production strategy. Academy of Management Review, 8(2), 301-310.

Morris, T., \& Empson, L. (1998). Organisation and expertise: an exploration of knowledge bases and the management of accounting and consulting firms. Accounting, Organizations and Society, 23(5/6), 609-624. 
Moule, C. (1998). Regulation of work in small firms: a view from the inside. Work, Employment and Society, 12(4), 635-653.

Phelps, R., Adams, R., \& Bessant, J. (2007). Life cycles of growing organizations: a review with implications for knowledge and learning. International Journal of Management Reviews, 9(1), 130 .

Rainnie, A. (1989). Industrial relations in small firms: small isn't beautiful. London: Routledge.

Ram, M. (1994). Managing to survive: working lives in small firms, Oxford: Blackwell.

Ram, M. (1999a). Managing autonomy: employment relations in small professional service firms. International Small Business Journal, 17(2), 13-30.

Ram, M. (1999b). Management by association Interpreting small firm-associate links in the business services sector. Employee Relations, 21(3), 267-284.

Ram, M. (2000). Investors in People in small firms: case study evidence from the business services sector. Personnel Review, 29(1), $69-91$.

Ram, M., \& Edwards, P. (2003). Praising Caesar not burying him: what we know about employment relations in small firms. Work, Employment and Society, 17(4), 719-730.

Ram, M., \& Edwards, P. (2010). Industrial Relations in small firms. In T. Colling, \& M. Terry (Eds.), Industrial Relations: theory and practice (pp. 231-252). Chichester: John Wiley \& Sons Ltd.

Ram, M., \& Holliday, R. (1993). Relative merits: family culture and kinship in small firms. Sociology, 27(4), 629-48.

Ram, M., Edwards, P., Gilman, P., \& Arrowsmith, J. (2001). The dynamics of informality: employment relations in small firms and effects of regulatory change. Work, Employment and Society, 15(4), 845-861.

Redman, T., \& Matthews, B. P. (1998). Service quality and human resource management: a review and research agenda. Personnel Review, 27(1), 57-77.

Rodwell, J., \& Shadur M. (1997). What's size got to do with it? Implications for contemporary management practices in IT companies. International Small Business Journal, 15(2), 51-62. 
Rutherford, M. W., Buller, P. F., \& McMullen, P. R. (2003). Human resource management problems over the life cycle of small to medium sized firms. Human Resource Management, 42(4), 321335.

Scase, R. (1995). Employment relations in small firms. In P. Edwards, (Ed.) Industrial Relations: theory and practice (pp. 569595). Oxford: Blackwell.

Scase, R. (2005). Managerial strategies in small firms. In S. Marlow, D. Patton, \& R. Ram (Eds.), Managing labour in small firms (pp. 66-82). Abingdon: Routledge.

Scholarios, D., \& Lockyer, C. (1999). Recruiting and selecting professionals: context, qualities and methods. International Journal of Selection and Assessment, 7(3), 142-156.

Scott, M., Roberts, I., Holroyd, G., \& Sawbridge, D. (1989). Management and industrial relations in small firms. London: Department of Employment.

Sheehan, M. (2013). Human resource management and performance: evidence from small and medium-sized firms. International Small Business Journal, Available OnlineFirst. DOI: $10.1177 / 0266242612465454$

Swart, J. (2007). HRM and knowledge workers. In P. Boxall, J. Purcell, \& P. M. Wright (Eds.), The Oxford Handbook of Human Resource Management (pp. 450-468). Oxford: Oxford University Press.

Swart, J. \& Kinnie, N. (2003). Knowledge-intensive firms: the influence of the client on HR systems. Human Resource Management Journal, 13(3), 37-55.

Tam, Y.-M.M., Korczynski, M., \& Frenkel, S.J. (2002). Organizational and occupational commitment: knowledge workers in large corporations. Journal of Management Studies, 39(6), 775801.

Taylor, S. (2005). The hunting of the snark: a critical analysis of human resource management discourses in relation to managing labour in smaller organizations. In S. Marlow, D. Patton, \& R. Ram (Eds.), Managing labour in small firms (pp. 18-42). Abingdon: Routledge. 
Torrès, O., \&Julien, P.-A. (2005). Specificity and denaturing of small business. International Small Business Journal, 23(4), 355377.

Verreynne, M-L., Parker, P., \& Wilson, M. (2013). Employment systems in small firms: a multilevel analysis. International Small Business Journal, 31(4), 405-431.

Wapshott, R., \& Mallett, O. (2013). The unspoken side of mutual adjustment: understanding intersubjective negotiation in small professional service firms. International Small Business Journal, 31(8): 978-996.

Watson, T. J. (1995). Entrepreneurship and professional management: a fatal distinction. International Small Business Journal, 13(2), 34-46.

Welsh, J.A., \& White, J.F. (1981), A small business is not a little big business. Harvard Business Review, (July-August 1981), 18-32.

Westhead, P., \& Storey, J. (1996). Management training and small firm performance: why is the link so weak? International Small Business Journal, 14(4), 13-24.

Wilkinson, A. (1999). Employment relations in SMEs. Employee Relations, 21(3), 206-217.

Williamson, I. O. (2000). Employer legitimacy and recruitment success in small businesses. Entrepreneurship Theory and Practice, 25(Fall), 27-42.

Yin, R.K. (2003). Case study research: design and methods. London: Sage. 